Article

\title{
Migration and Asylum Flows to Germany: New Insights Into the Motives
}

\author{
Felicitas Nowak-Lehmann *, Adriana Cardozo and Inmaculada Martínez-Zarzoso \\ Department of Economics, University of Göttingen, Germany; E-Mails: fnowak@uni-goettingen.de (F.N.-L.), \\ acardoz@uni-goettingen.de (A.C.), imartin@uni-goettingen.de (I.M.-Z.) \\ * Corresponding author
}

Submitted: 16 April 2021 | Accepted: 28 September 2021 | Published: 28 October 2021

\begin{abstract}
This study analyzes the determinants of both total migration and asylum migration to Germany. For the analysis, a comprehensive empirical model is set up that includes climate change, economic opportunities, such as per capita income differentials, links to Germany, home country characteristics (population growth, poverty, consumer confidence, unemployment), the political and institutional situation in the sending countries (measured by internal and external conflict, ethnic and religious tensions, government stability, law and order, military in politics), and a control for migration opportunities to alternative destinations. Panel data techniques (Poisson pseudo-maximum likelihood) for the estimation of the parameters of interest are employed using a panel of 115 (134) origin countries for asylum migration (total migration) over the period of 1996-2017 or 2001-2017, depending on data availability. The analysis reveals that political, socioeconomic, and economic factors determine both total migration and asylum migration. Economic factors are also determinants of asylum applications, as asylum seekers most often come for several reasons. Poverty plays a distinct role in total migration and asylum migration. An alleviation of poverty in origin countries is associated with less overall migration to Germany but with more asylum migration. Increases in average temperature also impact asylum migration in the expected direction, thus, increasing forced migration. The most interesting findings are revealed when considering country groupings (main migration countries, major asylum countries, countries whose asylum applicants enjoy high, intermediate, or low recognition rates).
\end{abstract}

\section{Keywords}

asylum flows; Germany; migration; migration motives; Poisson pseudo maximum likelihood estimation

\section{Issue}

This article is part of the issue "Migration and Refugee Flows: New Insights" edited by Inmaculada Martínez-Zarzoso (University of Göttingen, Germany / Jaume I University, Spain).

(C) 2021 by the authors; licensee Cogitatio (Lisbon, Portugal). This article is licensed under a Creative Commons Attribution 4.0 International License (CC BY).

\section{Introduction}

In 2015, Germany experienced more immigration flows from non-German born populations than any other year in this century. Since then, the inflow of migrants has been large but has started to slow. Asylum requests followed the migration with a 1-year lag peaking in 2016. The question remains as to what is still to come: Will there be smaller numbers of new (asylum) migrants, or will there be greater numbers of new arrivals in Germany in the medium or long run?

The varied reasons for migration and the difficulty to distinguish migration in the data makes statements on the desirability of immigration and a cost-benefit analysis of immigration to Germany rather difficult. Therefore, rather than focus on a cost-benefit analysis, which above all is not appropriate for asylum migration, in this article, we seek to investigate the most relevant reasons for migration and how migration responds to economic, socioeconomic, political, and climate-related changes in the countries of origin. Our analysis will allow us to ascertain the relative importance of the factors analyzed and to draw conclusions for several countries of origin that dominate migration flows to Germany. We analyze whether individuals from countries with high migration flows differ in their motivation to come to Germany from 
individuals coming from countries with lower migration flows. Finally, we investigate the extent to which asylum migration reacts to improvements in political factors such as ethnic tension and internal conflict, improvements in economic and socioeconomic conditions, and to variations of the asylum recognition rate.

Our study contributes to the existing literature by examining the impact and depth of the abovementioned factors that potentially influence total migration and asylum migration and by identifying the relative importance of these factors in relevant sub-groups of origin countries. To gain new and relevant insight, we first identify the top migrant-sending countries and the top home countries of asylum seekers (Section 2). Section 3 lays the ground for the empirical analysis, describing previous migration studies, data used, the modeling approach, and estimation techniques. In Section 4, we analyze the drivers and impediments of migration and asylum flows in general and for relevant sub-groups. We assess the type of factors (economic, socioeconomic, political, as well as climate-related factors) that have the greatest impact on migration and asylum migration, also for important country groups. We close with Section 5 , in which we discuss the results and derive a tentative policy conclusion.

\section{Migration and Asylum Migration}

In this section, we analyze the evolution over time and across origin countries of total migration, which includes asylum seekers, asylum migration-more precisely, gross migration and gross asylum migration inflows-and recognition rates. The many reasons for migration and/or asylum are not only at the macro level, which is considered in this article, but also at the individual level. Zahra (2016) speaks of "the great departure" and "mass migration" from Eastern Europe that includes migrants who migrate for not only work but also for family reunification. Migration inflows also capture migrants who relocate for studying, internships, or professional training, as well as refugees who travel to Germany to escape persecution, war, or a difficult humanitarian situation.

\subsection{Migration Flows}

Total immigration flows to Germany more than doubled from 574,800 to $1,384,000$ in the period 2007-2017 (see Table A1 in the Supplementary File). However, these inflows which also include late repatriates have been declining over the last three years, especially compared to 2015 when total immigration inflows reached 2,0162,000 (Bundesinstitut für Bevölkerungsforschung, 2020; OECD, 2019).

\subsection{Asylum Migration}

Asylum requests, more specifically, new asylum applications, reached their peak in 2016 with 722,364 indi- viduals applying for asylum in Germany (see Table A2 in the Supplementary File). In contrast, in 2018, there were only 161,930 new asylum requests. In that year, the top five asylum-seeking countries for new applications were Syria $(44,165)$, Iraq $(16,330)$, Iran $(10,855)$, Nigeria $(10,170)$, and Turkey $(10,160)$. They were followed by, in order of size, Afghanistan, Eritrea, Somalia, Russia, Georgia, Guinea, Pakistan, Albania, Azerbaijan, and Moldova.

\subsection{Recognition Rates}

Since 2008 , about $14-18 \%$ of annual asylum requests were approved. However, recognition rates of asylum seekers, i.e., positive asylum decisions (first instance asylum decisions) as a percentage of total asylum requests in a specific year vary by country of origin. Considering the period 2011-2017, recognition rates for individuals from major asylum-seeking countries were low (interval $[3 \% ; 15 \%])$ for Bosnia and Herzegovina, Georgia, and Macedonia, which we classify as low-range recognition origin-countries (Irecog). In the intermediate-range (interval [10\%; 35\%]) are Pakistan, Nigeria, Turkey, and Russia, classified as medium-range recognition countries (mrecog) and in the high-range (interval [40\%; 90\%]) are Afghanistan, Iraq, Syria, Eritrea, and Somalia, classified as high-range recognition countries (hrecog). The classification is based on figures and assessments of the Federal Office for Migration and Refugees (BAMF) and first instance administrative courts, and is used for further analysis.

\section{Empirical Analysis}

\subsection{Influential Studies}

This study builds on several case studies on Germany and on international migration that have examined migration flows from developing countries. Among them is the groundbreaking study by Rotte and Vogler (1998) who examined migration and asylum migration from developing countries to Germany for the period 1981-1995 and 1984-1995 respectively. Using a random effects model, the estimation results point to the importance of income differentials between countries, the potential existence of a U-shaped relationship between development and migration, as well as to the importance of network effects. The political factors entering the model contradict each other. Deteriorations of the political terror scale increase emigration whereas a deterioration of political rights or civil liberties seem to decrease emigration. In more recent years, Grote (2018) and Ayoub (2019) investigated Germany's response to (asylum) migration. Müller et al. (2012), as well as Gröschl and Steinwachs (2017), analyzed migration due to climate change and natural disasters. The former found it difficult to disentangle climate-related migration from other motives due to data constraints and methodological 
issues, whereas the latter found little evidence that natural hazards affect medium to long-run international migration. Other relevant studies that focus on the determinants of migration and asylum migration and for other migrant receiving countries are Bertoli et al. (2016, 2020), Hatton (2004, 2009, 2016, 2017, 2020), Hatton and Moloney (2015), Hoeffler (2013), Kang (2021), and Winter (2020), among others.

Studies covering several destination countries, such as Grogger and Hanson (2011), stress the importance of self-selection depending on the migrant's education and opportunities in the destination countries; Bertoli and Fernández-Huertas Moraga (2013a, 2013b) and Bertoli et al. (2016) point to the sequential nature and the importance of alternative destinations in the migration decision. In both their 2013 papers, Bertoli and Fernández-Huertas Moraga show that ignoring the sequential nature of migration decisions gives rise to multilateral resistance to migration, thus substantially biasing the estimates.

Concerning the drivers of international migration, Grogger and Hanson (2011) provide an integrated framework to examine the fraction of population that emigrates addressing migrant selectivity according to skills and evaluating the importance of wage differences in the migration process. Their findings indicate that destinations with liberal asylum policies attract relatively low-skilled immigrants, controlling for other factors. However, the authors conclude that the sparseness of data for which to compare destination country regimes limits their ability to examine the influence of policies. Hatton (2016) investigates the determinants of asylum flows from 48 origin countries to 19 OECD destinations over the period 1997-2012 and finds that political terror has one of the strongest effects among the factors at origin, while lack of civil liberties shows a weaker effect. However, lack of political rights does not have the expected effect, and neither does civil war deaths. Similarly, Kang (2021) investigates the determinants of asylum seeking, for a sample of seven EU receiving countries and 145 origin countries, finding that greater political stability in the origin country significantly reduces emigration rates.

More recently and parallel to our study, Winter (2020) investigates the dynamics of the determinants of immigration to EU member countries over almost two decades focusing on political and economic factors. He finds that the latter appear to outweigh the former in importance. In particular, better economic conditions can have a two-sided effect as they can reduce the incentive to migrate or make migration feasible due to an eased budget constraint, whereas improvements in political conditions in the origin country decrease migration.

Some of the findings from the previous studies could benefit from further clarification, calling for a study that addresses the impact and depth of all factors that potentially influence migration and asylum migration in more detail. For instance, the potential U-shaped relationship addressed by Rotte and Vogler (1998) and Winter (2020) between economic development and migration needs further study and a close look at socioeconomic factors (in particular, the role of poverty in origin countries). Moreover, the results concerning the role of political factors are inconsistent in Rotte and Vogler (1998) for the case of Germany as a destination country. Thus, we think that data from the International Country Risk Guide (ICRG; PRS Group, 2019) to describe the political situation in the countries of origin are a better choice (also see Table A3 in the Supplementary File).

We contribute to the literature by performing an in-depth analysis of the role of economic, socioeconomic and political factors in origin countries. By splitting the socioeconomic factors in their sub-categoriespoverty, unemployment, and consumer confidenceand the political factors in their sub-categories-ethnic tension and internal conflict-we also gain a nuanced understanding of the main differences between migration and asylum migration.

Finally, we contribute to the existing literature by taking a close look at the socioeconomic determinants of migration from specific country groups, such as high and medium inflow countries and from EU and non-EU countries. Moreover, we study the relative importance of political and socioeconomic aspects of asylum migration, and differentiate the analysis by country groups with high, medium, and low recognition rates and differentiate between major origin countries and countries with a "no return policy."

\subsection{Data and Variables}

We build on OECD $(2019,2020)$ data to depict migration inflows to Germany and the development of asylum requests in Germany. The data on sending-countryspecific migration, asylum, and recognition rates in Germany are taken from the OECD, which in turn collects data from different national and international sources. Unfortunately, the data does not include the education and skill level of the migrants.

Relevant bilateral migration-related data have been collected by country of origin and destination (Germany). Original migration data for Germany stem from the local population registers; asylum-related data come from the BAMF and the local registers which are usually informed by the BAMF and administrative courts (Verwaltungsgerichte) on asylum requests, pending decisions, and positive (accepting) and negative (rejecting) decisions. Asylum seekers are classified according to their passports, i.e., Afghans who resettle from Iran to Germany after their situation in Iran has deteriorated are counted as asylum seekers from Afghanistan.

Migrant stocks prior to arrival, an indicator of migrant networks, have also been obtained from the OECD. Data on demographics (population, population growth, per capita income, etc.) were collected from the World Bank (2020). To control for the relative attractiveness 
of non-German destinations we construct a bias control variable. To this end we have used OECD data with information on bilateral migration (asylum flows) to all OECD countries. Using this larger database, we compute the flows to non-German destinations as a share of total flows (to Germany and non-German destinations) for each origin country and year. Data on socioeconomic, political, and institutional factors in the sending countries stem from the ICRG. The ICRG's computed political risk measures are the only ones accepted by courts in commercial disputes, transnational firms, institutional investors, hedge funds, central banks, and multilateral organizations. In the ICRG data, points are given for each category, where higher scores mean an improvement of the situation (see Table A3 in the Supplementary File). From the ICRG dataset, we utilize the following variables: socioeconomic conditions (poverty, unemployment, and consumer confidence) and political factors (ethnic tensions and internal conflict). Climate-related data, such as average, minimum, maximum temperature, and precipitation data are taken from the World Bank (2020).

\subsection{Modeling Approach and Estimation Technique}

Since Germany is the host country for all sending countries in this study, we mainly focus on the push factors of emigration. This implies that we model the host country, i.e., Germany, rather parsimoniously, including the relevant (bilateral) migrant networks, the income differential between Germany and the sending country, and year dummies.

Moreover, we emphasize not only the demographic, economic, and socioeconomic factors in sending countries (i.e., population pressure, unemployment, consumer confidence, poverty), but also investigate political factors such as government stability, military in politics, institutional factors such as law and order, and security aspects such as ethnic tensions, external conflict, internal conflict, and religious tensions. Among the politicalinstitutional-security aspects, only ethnic tensions and internal conflict proved to be robust determinants of (asylum) migration and hence only the latter eventually appear in the regressions. Network effects are considered as well (Beine et al., 2011) and climate-related aspects such as average temperature or average precipitation are also included (Backhaus et al., 2015).

We use panel data techniques for the estimation of the parameters of interest using a panel of a maximum of 134 origin and sending countries over a maximum period of 22 years so that regressions run from 1996 to 2017 (2001-2017) for total migration (asylum inflows), and from 2000 to 2018 for sending country-specific asylum recognition rates. The periods differ due to data availability, since asylum inflows are only reported after 2000 and the ICRG data on poverty, unemployment, and consumer confidence are only available after 2001 . We have an unbalanced panel as we have missing values. Because we also have true zeros, we utilize the Poisson pseudo- maximum likelihood estimation technique, which also takes account of heteroscedasticity in the error terms.

Since migration is a complex process, for example, migration and asylum migration and recognition rates might be intertwined, we analyze their determinants in two different models. We investigate two types of bilateral flows to Germany, looking at two different dependent variables: (a) migrant inflows and (b) asylum seeker inflows (both as a function of migrant networks and demographic, economic, socioeconomic, political, and climate-related factors).

We use country fixed effects for sending countries to control for sending country's time-invariant characteristics, such as geography, being land-locked, ethnic composition or fractionalization, language, colonial history, etc. As origin country fixed effects allow us to completely control for time-invariant country heterogeneity, they are preferred to the inclusion of time-invariant characteristics given that these are sometimes difficult to quantify or to observe. Following Bertoli and Fernández-Huertas Moraga (2013a, 2013b) and Bertoli et al. (2016), we also control for bias induced by time-varying attractiveness of alternative destinations by including a variable that measures the share of alternative (non-German) migration flows in total OECD migration flows over time. This variable reflects not only differences in economic attractiveness but also differences in migration and asylum policy between destination countries.

To control for potential endogeneity of the independent variables, we lag these variables by one year. These lags are meant to also capture the reaction-lags related to migration decisions as information has to be gathered and assessed since emigration must be prepared and these steps take some time. It is important to mention that using lags only mitigates endogeneity due to reverse causality but cannot address endogeneity issues due to omitted variables.

\section{Empirical Model and Findings}

\subsection{Migration Inflows}

We follow the general migration literature to develop our model of migrant inflows. Given that the migration literature is extensive, we concentrate on a few key articles and their findings. Mayda (2010) uses push and pull factors in her analysis of bilateral immigration flows into 14 OECD countries using per capita income at the destination and origin, distance, common language, colony, years of schooling, capital per worker at destination and origin, demographics, such as share of young population at origin, and changes in immigration policy at destination as relevant factors of international migration. Her econometric analysis shows that changes in immigration policy in the destination country are a crucial determinant of immigration flows. Per capita income in the destination countries acts as a pull factor, whereas per capita income at the origin seems irrelevant. The share 
of young population at origin and distance between origin and destination also contributes to explaining migration flows. The rest of the factors are insignificant. Other studies (Giulietti et al., 2013; van Meeteren \& Pereira, 2018; Villarrubia-Mendoza, 2016) emphasize the role of migrant networks in facilitating immigration and finding housing and a job. De Haas et al. (2019) discuss the push and pull factors of international migration in their excellent overview paper also pointing to the role of political rights and political freedom as drivers of emigration. Based on their econometric analysis, they state that the impact of political factors is not so clear-cut saying that while authoritarianism might increase migration aspirations, it might decrease migration capabilities. In our study, we build on these studies to try to establish the relative strength of the impact of single factors on international migration to be better able to shape the policy response towards immigration.

The dependent variable in our model is the inflow of migrants migrant_in $n_{j t}$ from country-of-origin $j$ at time $t$ (Equation 1) respectively:

$$
\begin{aligned}
& \text { migrant_in }_{j t}=\exp \left(\alpha_{j}+\beta_{1} \ln \left(\text { migrant_stock }_{j t-1}\right)\right. \\
& +\beta_{2} \text { population_pressure }{ }_{j t-1}+\beta_{3} \text { relative_pcincome }_{j t-1} \\
& +\beta_{4} \text { socioecon_factors }_{j t-1}+\beta_{5} \text { political_factors } \\
& j t-1 \\
& \left.\left.+\beta_{6} \text { weather_factors }_{j t-1}\right)+\beta_{7} \text { bias_control }_{j t-1}+\phi_{t}\right) \\
& \times u_{j t}
\end{aligned}
$$

Migration inflows migrant_in ${ }_{j t}$ are assumed to react with a certain time lag to changes in network size, demography, real per capita income, socioeconomic conditions, such as poverty, unemployment, consumer confidence, and changes in political factors, such as ethnic tensions and internal conflict that affect security.

The stock of migrants coming from country $j$ that have settled so far in the host country, migrant_stock ${ }_{j t-1}$, is a proxy for the size of the network (size of population of sending country living in Germany) and the network effect. A positive effect is expected as an agglomeration of migrants from the same country of origin makes emigration easier and can decrease migration costs. Compatriots living in the destination country can provide information on migration routes, on housing and employment possibilities and they can alleviate homesickness by providing a community which shares the same values and norms. At a more practical level, this community can also make it possible to keep the same food habits.

Population pressure population_pressure ${ }_{j t-1}$ is measured by the difference in population growth rate between sending country $j$ and Germany (DEU). An increase in this difference is expected to drive people out of their home countries. The higher the population growth rate in the sending country via-à-vis Germany, the higher is the relative population pressure, i.e., job opportunities in the sending country and access to services deteriorate due to over-crowding.
The ratio of per capita income, relative_pcincome ${ }_{j t-1}$, in the country of origin with respect to per capita income in Germany is an indicator of the relative economic performance in the home country compared to Germany. An increase in this ratio is therefore expected to reduce emigration from the home country.

Also, an improvement in socioeconomic conditions, socioecon $_{j t-1}$, which goes hand in hand with higher consumer confidence, lower unemployment, and lower poverty, could detain individuals from migrating and hence, a negative sign is expected. Hence, the subcategories of socioeconomic factors provided by ICRG are poverty, unemployment, and consumer confidence (see Table A3 in the Supplementary File).

An increase in political risk factors, political factors $_{j t-1}$, is defined as an improvement in the political, institutional, and security situation, in the year prior to emigration. Hence, we expect that an improvement will lead to a decrease in emigration, and we expect a negative coefficient. The sub-categories that proved robust are ethnic tensions and internal conflict (see Table A3 in the Supplementary File).

In terms of climate-related factors, weather factors $_{j t-1}$, we look at both an increase in average temperature and an increase in average precipitation. We expect that increases in average temperature/precipitation will increase the number of climate refugees. Increases in average temperature will lead to more droughts, a decline in agricultural production and, hence, a deterioration of living conditions not only in rural areas but also in urban areas where rural exodus causes congestion. In the same vein, increases in average precipitation will lead to more floods, a decline in agricultural production, and destruction of living conditions.

An increase in the share of migration to non-German destinations reduces migration to Germany and serves as bias_control $t_{t-1}$. It takes account of the fact that migrants can choose among destinations.

Equation 1 is slightly altered (in Table 1, columns 1-4) to check whether results are robust. In Table 1, column 1, time-invariant gravity variables are used instead of origin fixed effects. This model performs worst in terms of explanatory power (pseudo- $\mathrm{R}^{2}$ ). Origin country fixed and year fixed effects (Table 1 , column 4 ) are used in Equation 1 and the results produced there are compared to models that include either a time trend (Table 1, column 3 ) or a time dummy (Table 1, column 2) which takes the value of 1 after 2014

The coefficients of the variables in logs depict elasticities and can be interpreted directly, whereas the coefficients of unlogged variables are semi-elasticities. To compute their impact, we calculate: $[\exp (\beta)-1] \times 100$, where beta is the regression coefficient listed in the tables. All our explanatory variables are lagged by one period to reflect reaction lags but also to mitigate endogeneity issues. The right-hand side variables can be considered predetermined variables and their impact can be considered as causal since migration at time ' $t$ ' will hardly have 
Table 1. Determinants of immigration to Germany from 134 countries.

\begin{tabular}{|c|c|c|c|c|}
\hline $\begin{array}{l}\text { Dependent variable } \\
\text { Immigration to Germany from all countries }\end{array}$ & $\begin{array}{c}\text { (1) } \\
\text { Immigration }\end{array}$ & $\begin{array}{c}(2) \\
\text { Immigration }\end{array}$ & $\begin{array}{c}\text { (3) } \\
\text { Immigration }\end{array}$ & $\begin{array}{c}\text { (4) } \\
\text { Immigration }\end{array}$ \\
\hline \multicolumn{5}{|l|}{ Explanatory variables (all lagged by one period) } \\
\hline $\begin{array}{l}\text { Accumulated migration stock (in logs) } \\
\text { (Network effect) }\end{array}$ & $\begin{array}{l}0.712^{* * *} \\
(0.002)\end{array}$ & $\begin{array}{l}0.772 * * * \\
(0.002)\end{array}$ & $\begin{array}{l}0.716^{* * *} \\
(0.002)\end{array}$ & $\begin{array}{l}0.708^{* * *} \\
(0.002)\end{array}$ \\
\hline Population pressure & $\begin{array}{l}0.041^{* * *} \\
(0.011)\end{array}$ & $\begin{array}{l}0.079 * * * \\
(0.000)\end{array}$ & $\begin{array}{l}0.040^{* * *} \\
(0.000)\end{array}$ & $\begin{array}{l}0.026 * * * \\
(0.001)\end{array}$ \\
\hline Relative per capita income & $\begin{array}{l}-0.018^{* * *} \\
(0.000)\end{array}$ & $\begin{array}{l}-0.017^{* * *} \\
(0.000)\end{array}$ & $\begin{array}{l}-0.018 * * * \\
(0.000)\end{array}$ & $\begin{array}{l}-0.016 * * * \\
(0.000)\end{array}$ \\
\hline ICRG rating poverty & $\begin{array}{l}-0.154 * * * \\
(0.002)\end{array}$ & $\begin{array}{l}-0.106 * * * \\
(0.002)\end{array}$ & $\begin{array}{l}-0.167^{* * *} \\
(0.002)\end{array}$ & $\begin{array}{l}-0.142 * * * \\
(0.002)\end{array}$ \\
\hline ICRG rating unemployment & $\begin{array}{l}-0.068^{* * *} \\
(0.001)\end{array}$ & $\begin{array}{l}-0.063^{* * *} \\
(0.001)\end{array}$ & $\begin{array}{l}-0.064^{* * *} \\
(0.001)\end{array}$ & $\begin{array}{l}-0.053^{* * *} \\
(0.001)\end{array}$ \\
\hline ICRG rating consumer confidence & $\begin{array}{l}-0.056^{* * *} \\
(0.001)\end{array}$ & $\begin{array}{l}-0.042^{* * *} \\
(0.001)\end{array}$ & $\begin{array}{l}-0.062^{* * *} \\
(0.001)\end{array}$ & $\begin{array}{l}-0.044^{* * *} \\
(0.001)\end{array}$ \\
\hline ICRG rating ethnic tensions & $\begin{array}{l}-0.178 * * * \\
(0.001)\end{array}$ & $\begin{array}{l}-0.209 * * * \\
(0.001)\end{array}$ & $\begin{array}{l}-0.176^{* * *} \\
(0.001)\end{array}$ & $\begin{array}{l}-0.188^{* * *} \\
(0.001)\end{array}$ \\
\hline ICRG rating internal conflict & $\begin{array}{l}-0.077^{* * *} \\
(0.001)\end{array}$ & $\begin{array}{l}-0.116^{* * *} \\
(0.000)\end{array}$ & $\begin{array}{l}-0.078^{* * *} \\
(0.001)\end{array}$ & $\begin{array}{l}-0.065^{* * *} \\
(0.001)\end{array}$ \\
\hline Average temperature, in Celsius & $\begin{array}{l}-0.022 * * * \\
(0.001)\end{array}$ & $\begin{array}{l}0.018^{* * *} \\
(0.001)\end{array}$ & $\begin{array}{l}-0.021 * * * \\
(0.001)\end{array}$ & $\begin{array}{l}-0.012 * * * \\
(0.001)\end{array}$ \\
\hline Average precipitation, in $\mathrm{mm}$ & $\begin{array}{l}0.003^{* * *} \\
(0.000)\end{array}$ & $\begin{array}{l}0.005^{* * *} \\
(0.000)\end{array}$ & $\begin{array}{l}0.003^{* * *} \\
(0.000)\end{array}$ & $\begin{array}{l}0.001 * * * \\
(0.000)\end{array}$ \\
\hline Contiguity & $\begin{array}{c}0.461 \\
(0.780)\end{array}$ & & & \\
\hline Common official language & $\begin{array}{c}1.111 \\
(0.954)\end{array}$ & & & \\
\hline Former colony & $\begin{array}{c}-0.497 \\
(0.922)\end{array}$ & & & \\
\hline $\begin{array}{l}\text { Distance in logs (simple distance between most } \\
\text { populated cities, } \mathrm{km} \text { ) }\end{array}$ & $\begin{array}{l}-0.390 * * \\
(0.131)\end{array}$ & & & \\
\hline $\begin{array}{l}\text { Share of migration to all other countries } \\
\text { (bias control) }\end{array}$ & $\begin{array}{l}-1.114 * * * \\
(0.011)\end{array}$ & $\begin{array}{l}-2.809 * * * \\
(0.012)\end{array}$ & $\begin{array}{l}-1.107^{* * *} \\
(0.011)\end{array}$ & $\begin{array}{l}-2.645^{* * *} \\
(0.016)\end{array}$ \\
\hline Time trend & & & $\begin{array}{l}0.032^{* * *} \\
(0.000)\end{array}$ & \\
\hline Dummy for year_after_2014 & & $\begin{array}{l}-0.017^{* * *} \\
(0.001)\end{array}$ & & \\
\hline Observations & 1,959 & 1,968 & 1,968 & 1,968 \\
\hline Number of origin countries & 133 & 134 & 134 & 134 \\
\hline Origin fixed effects & No & Yes & Yes & Yes \\
\hline Time fixed effects & Yes & Time dummies & Trend & Yes \\
\hline Pseudo- $R^{2}$ (not adjusted for degrees of freedom) & 0.854 & 0.954 & 0.957 & 0.958 \\
\hline
\end{tabular}

Notes: Standard errors in parentheses; ${ }^{* * *} p<0.01,{ }^{* *} p<0.05, * p<0.1$; period 2001-2017; an increase in the socioeconomic (poverty, unemployment, and consumer confidence) and political variables (ethnic tensions and internal conflict) implies an improvement so that a negative sign is expected; the sub-components poverty, unemployment, and consumer confidence are only available from 2001 onwards; all variables are from the perspective of the origin country. 
an impact on migrant stock, nor on the political, socioeconomic, economic, and climate-related factors of the previous period.

In Table 1, most of the coefficients carry the expected sign. To demonstrate the robustness of our results we show in column 1 a version of the model with year fixed effects but without origin fixed effects. Instead, gravity factors, such as contiguity, common language, colonial relationship, and distance are included. Here, pseudo- $R^{2}$ is lowest as expected since other time-invariant factors of origin countries are not captured. Column 2 presents the model with origin fixed effects and a time dummy after 2014 and column 3 includes origin fixed effects and a time trend.

We focus on column 4 with origin country and year fixed effects. Larger migrant networks make immigration easier and can decrease immigration costs. Hence, they are associated with an increase in migration inflows to Germany. A $1 \%$ increase in migrant networks increases emigration by about $0.71 \%$. A higher population pressure at origin makes the home country relatively less attractive and Germany an even more promising choice. We find that an increase in relative population pressure by 1 percentage point increases immigration by about $3 \%$. When per capita income in the country of origin improves in relative terms (e.g., by 1 percentage point) this improvement in per capita income reduces immigration by about $2 \%$.

In contrast, the interpretation of the socioeconomic and political factors is not straightforward because the point range can vary from factor to factor. The point range for the ICRG-factors (socioeconomic conditions, political risk categories) is listed in Table A3 in the Supplementary File and is crucial for the computation of semi-elasticities.

\subsubsection{Impact of Socioeconomic and Political Factors (Proportional, Less Than, or More Than Proportional)}

We choose the wording "proportional" to have a measure of the relative strength. We do not imply that a proportional reaction is a normal reaction and that disproportionately high/low are abnormal reactions.

Socioeconomic conditions (poverty, unemployment and consumer confidence) are measured by points ranging from 0 (lowest/worst level) to 4 (best condition). One point (unit) corresponds to 20 percentage points. An improvement of socioeconomic conditions (i.e., less poverty, less unemployment, and higher consumer confidence which may indicate better employment opportunities) in the country of origin reduces migration in a less than proportional way. For instance, a 1-unit increase (which corresponds to an improvement of 20 percentage points of poverty, unemployment, and consumer confidence) reduces immigration by $13 \%, 5 \%$, and $4 \%$, respectively. The results are computed in the following way:
- Unemployment: $[\exp (-0.053)-1]=-0.052$

- Consumer confidence: $[\exp (-0.044)-1]=-0.043$ ]

As to the role of political factors, a 1-unit improvement in ethnic tensions ( 1 unit corresponds to 14 percentage points) reduces immigration by $17 \%$. A 1 -unit improvement in internal conflict ( 1 unit corresponds to eight percentage points) decreases immigration by $6 \%$. The results are computed as follows:

- Ethnic tensions: $[\exp (-0.188-1)=-0.171]$

- Internal conflict: $[\exp (-0.065)-1=-0.063]$

The regression coefficients so far are all statistically significant and robust across columns 1-4.

Increases in average temperature (by 1 degree Celsius) slightly decrease emigration (columns 1, 3, and 4) but increase immigration using a time dummy that is coded as 1 after 2014 (column 2). Hence, the result concerning the role of temperature is not robust. A 1-unit change by $1 \mathrm{~mm}$ in precipitation increases immigration by $0.1 \%$.

An increase in the migration share to destinations different from Germany is associated with less migration to Germany, which implies a substitution effect and could be the result of stricter immigration measures in Germany. Please note that this variable should be considered as bias control since it reflects the attractiveness of alternative destinations.

\subsubsection{Important Findings for Sub-Groups}

Table B1 in the Supplementary File looks deeper into migration patterns of "high inflow" (hinflow) and "intermediate inflow" (minflow) countries which comprise China and India. In the "high inflow" group are countries mostly from the South and South-East European region, such as Romania, Poland, Bulgaria, Croatia, Italy, Hungary, Greece, Turkey, Serbia and Montenegro, and Bosnia and Herzegovina. Individuals from these countries mainly come to work or for family reunification (Sachverständigenrat deutscher Stiftungen für Integration und Migration, 2010). China and India represent "medium inflow" countries. Individuals from these countries go to Germany to study, to complete internships, and to work (Deutscher Bundestag, 2014). In general, the results obtained for all countries are not always corroborated in our two sub-samples.

We find high heterogeneity in our sub-group results. We observe that the results for non-EU countries drive our overall results. Socioeconomic conditions have different effects in different sub-groups. Improvements in poverty, unemployment and consumer confidence by 1 point reduce immigration from non-EU countries by $5 \%$, $15 \%$, and $10 \%$ respectively. An improvement in ethnic tensions reduces immigration flows from all sub-groups.

- Poverty: $[\exp (-0.142)-1]=-0.13$ 


\subsection{Asylum Migration}

We build our study on previous work, include additional socioeconomic and political variables, and add a new aspect, namely the role played by asylum recognition rates. Davenport et al. (2003) studies asylum migration identifying the role of civil war, genocide, and political regimes on worldwide asylum migration. Hatton (2009, 2017) shows that political terror and a lack of civil liberties are drivers of asylum migration, more than conflict. Proximity and access are also relevant for the volume of asylum flows and, to a smaller extent, economic conditions as well (Bertoli et al., 2020; Hatton, 2009). The growth of transit routes and migrant networks lead to an upward trend of asylum applications from more distant countries of origin (Hatton, 2020). According to Capps et al. (2019), travel in caravans, existing migrant networks, droughts and conflict at home, and immigration policy of the destination country fuel increases in asylum inflows from Central America to the US. Moreover, Missirian and Schlenker (2017) find that asylum applications respond to temperature fluctuations. Our dependent variable is the number of asylum seekers asylum_in ${ }_{j t}$ (Equation 2) from country-of-origin $j$ at time $t$ respectively:

$$
\begin{aligned}
& \text { asylum_in }_{j t}=\exp \left(\alpha_{j}+\beta \text { recogniton_rate }_{j t-1}\right. \\
& \left.+x_{1} \ln \text { (migrant_stock } k_{j t-1}\right) \\
& \left.+x_{2} \text { population_pressure }{ }_{j t-1}\right) \\
& +x_{3} \text { relative_pcincome }{ }_{j t-1}+x_{4} \text { socioecon }_{j t-1} \\
& \left.+x_{5} \text { political_factors } \text { prt-1 }_{j t}+\delta \text { weather_factors }_{j t-1}\right) \\
& \left.+\gamma \text { bias_control }_{j t-1}+\phi_{t}\right) \times v_{j t}
\end{aligned}
$$

The inflow of asylum seekers is assumed to react with a certain time lag to changes in the explanatory variables: the recognition rates for asylum seekers of the country of origin in Germany; the stock of compatriots already living in Germany (network size); population growth in the country of origin (population pressure), which leads to fierce competition for resources; changes in socioeconomic factors and political factors relating to security (internal conflict and ethnic tensions); weather factors; and the attractiveness of other European asylum destinations (bias control). The time lag also reflects the fact that asylum requests can be filed even months after arrival in Germany. Moreover, asylum migration of family members does not take place at short notice but takes place in a more orderly manner, usually after the head of the household/family has been granted asylum.

Equation 2 is slightly altered (in Table 2, columns 1-4) to check whether results are robust. In Table 2, column 1, time-invariant gravity variables are included instead of origin fixed effects. This model performs worst in terms of explanatory power (pseudo- $\mathrm{R}^{2}$ ). Origin country and year fixed effects (Table 2, column 4) are used in Equation 2 and compared to models that include either a time trend (Table 2, column 2) or a time dummy (Table 2, column 3), which takes the value of 1 after 2014, zero otherwise.

The year fixed effects are supposed to absorb changes over time that concern all origin countries. Hence, they can reflect changes in the German asylum policy over the years that are common to all origin countries. Iglit and Klotz (2018) illustrate the multiple shades of German asylum policy. They point out that German asylum policy since the mid-1990s until present day has always included both progressive/liberal and restrictive/conservative elements. On the progressive side, persecution by non-state agents was recognized as a reason for asylum and there were relaxed residence and employment restrictions for refugees. In May 2016, the First Refugee Integration Law offered asylum seekers easier access to the German labor market. On the restrictive side, the list of safe countries was extended, including Serbia, Bosnia and Herzegovina, Macedonia, Kosovo, and Albania. Since March 2016, Syrians have been required to apply for asylum individually, as opposed to the earlier procedure of full protection for this population group.

We also include as a control variable bias_control ${ }_{j t-1}$, which is the share of asylum migration that goes to nonGerman European destinations. This variable captures not only the relative economic attractiveness of other destinations, but also the role played by asylum policy in Germany and other destinations over time and takes account of the fact that Germany is not the only destination for asylum seekers.

The asylum recognition rate of the previous period, recognition_rate $_{j t-1}$, is also included as an additional explanatory variable. It is assumed that information on the chances of getting recognized as an asylee by German authorities when coming from a specific home country is shared via social media (Facebook, WhatsApp, Instagram) and email. We expect that an increase in recognition rates induces more people to leave their home country given the political, institutional, and (socio)economic problems that prevail in the sending country.

Similarly, as we did for total migration, we start by interpreting the results in Table 2, column 4, which shows regression results for a model with origin and year fixed effects.

An increase in the recognition rate (by 1 percentage point) in the previous period increases the number of asylum requests by about $2 \%$, which can be considered a minor change.

The network effect is not very substantial either since an increase in network size by $1 \%$ increases asylum requests by $0.2 \%$. This implies that other motives to seek asylum are much more relevant.

Population pressure in the country of origin does not carry the expected positive sign in column 4 . Results in columns 2 and 3 indicate that population pressure strongly increases the number of asylum seekers in 
Germany. These models are potentially superior to the model in column 4 with year fixed effects as the adjusted pseudo- $R$ squared is larger because more degrees of freedom remain in the regressions. If the population growth accelerates by 1 percentage point (which is a huge increase), asylum requests would increase by $55 \%$ (column 2 ) or $44 \%$ (column 3 ).

An increase in relative per capita income of the country of origin with respect to Germany's per capita income by 1 percentage point reduces asylum requests by about $13 \%$. This impact is disproportionately high.

As before, the interpretation of the socioeconomic and political factors is trickier: A 1-point improvement in consumer confidence and unemployment in the home country reduces asylum requests by about $5 \%$ and $3 \%$ respectively. This impact is disproportionately low given that both consumer confidence and unemployment range from 0 to 4 points and 1 point corresponds to about 20 percentage points. However, a 1-point improvement (20 percentage points) in poverty leads to a more than proportionate increase in asylum migration by $45 \%$. This phenomenon is known from microeconomic studies in which income is shown to have an inverse $\mathrm{U}$-shaped impact on migration. The poorest cannot afford to emigrate, but the middle class can cover travel expenses and the first weeks abroad and leave the home country. The richer segments of society migrate less as they are well respected members of society that can lead a pleasant life back home.

Interestingly, improvements in poverty have a reverse effect on asylum migration as they seem to spur emigration making emigration feasible and affordable. This is different when we look at general migration (Table 1). Here, an alleviation of poverty diminishes migration by improving the relative per capita income with respect to the destination country. This might signal a U-shaped relationship between economic development and migration and has been discussed by Winter (2020).

In terms of political factors, we find the following results for the sub-categories of political risk: ethnic tensions and internal conflict, which proved to be robust drivers of asylum migration. A 1-point improvement in ethnic tension reduces asylum requests by $11 \%$ and a 1-point improvement in internal conflict reduces asylum requests by $3 \%$. Given that 1 point corresponds to about $14 / 8$ percentage points, respectively (ethnic tensions range from 0 to 6 points and internal conflict ranges from 0 to 12 points), these are less than proportionate declines.

Both temperature increases and increases in precipitation by 1 unit ( 1 degree Celsius and $1 \mathrm{mml}$ respectively), increase asylum requests by $24 \%$ and $2 \%$ respectively. We argue that this is due to a deterioration of living conditions.

A further finding is that a higher share of asylum flows to other European countries reduces asylum flows to Germany.
In Table B2 in the Supplementary File we present several robustness checks in columns $2-4$. In column 2 we use a different bias control, namely the share of asylum migration that goes to transit countries (Greece, Hungary, Spain, and Turkey). In column 3 we do not utilize the recognition rate which is the share of positive asylum decisions in total decisions (negative and closed) but the log of positive asylum decisions. In column 4 we substitute asylum applications by recognized asylum applications (positive asylum decisions). As expected, the alteration of the dependent variable increases the role played by an improvement of ethnic tensions and internal conflict in granting less asylum and reducing positive asylum decisions.

\subsubsection{Main Findings for Sub-Groups}

To elaborate on what happens within the group of asylum seekers, we analyze the reaction to changes and improvements in (a) ethnic tensions and (b) internal conflict for two sub-groups (see Table B3 in the Supplementary File).

In the group of major asylum-seeking countries, abbreviated as "major" (Syria, Iraq, Afghanistan, Bosnia and Herzegovina, Serbia, Macedonia, Albania, Georgia, Russia, Turkey, Somalia, Nigeria, Eritrea, and Pakistan; see Table B3, column 1, in the Supplementary File) we find that a 1-point improvement of ethnic tensions reduces immigration to Germany by $7 \%$, and a 1-point improvement of internal conflict decreases immigration to Germany by $8 \%$. Asylum seekers of this sub-group react only moderately to improvements in ethnic tensions and about proportionately to improvements in internal conflict.

Furthermore, we find that a 1-point improvement of ethnic tensions reduces immigration to Germany by $10 \%$ and a 1-point improvement of internal conflict reduces immigration to Germany by $10 \%$ in countries with nonreturn policy, "non-return." These include countries such as India, Pakistan, Bangladesh, Lebanon, Algeria, Egypt, Morocco, Mali, Nigeria, Niger, Ethiopia, Tunisia, Ghana, Guinea, Guinea-Bissau, Burkina Faso, and Benin, that have difficulties in taking back asylum seekers whose asylum request has been rejected by German authorities (see Table B3, column 3, in the Supplementary File). Asylum seekers of this sub-group seem to react moderately with respect to improvements of ethnic tensions and to react more strongly with respect to improvements of internal conflicts.

\subsubsection{The Role of Recognition Rates for Certain Sub-Groups}

When looking at the determinants of recognition rates we find that almost all political and institutional factors are considered relevant by decision-makers (see Table B4 in the Supplementary File). 
Table 2. Determinants of asylum requests in Germany from 115 nationalities.

\begin{tabular}{|c|c|c|c|c|}
\hline $\begin{array}{l}\text { Dependent variable } \\
\text { Asylum requests from all countries }\end{array}$ & $\begin{array}{c}(1) \\
\text { Asylum }\end{array}$ & $\begin{array}{c}(2) \\
\text { Asylum }\end{array}$ & $\begin{array}{c}\text { (3) } \\
\text { Asylum }\end{array}$ & $\begin{array}{c}\text { (4) } \\
\text { Asylum }\end{array}$ \\
\hline \multicolumn{5}{|l|}{ Explanatory variables (all lagged one period) } \\
\hline Recognition rate for asylum requests & $\begin{array}{l}0.017^{* * * *} \\
(0.000)\end{array}$ & $\begin{array}{l}0.019 * * * \\
(0.000)\end{array}$ & $\begin{array}{l}0.019 * * * \\
(0.000)\end{array}$ & $\begin{array}{l}0.017^{* * *} \\
(0.000)\end{array}$ \\
\hline Accumulated migration stock (in logs) & $\begin{array}{l}0.211^{* * *} \\
(0.005)\end{array}$ & $\begin{array}{l}-0.099 * * * \\
(0.005)\end{array}$ & $\begin{array}{l}-0.065^{* * *} \\
(0.005)\end{array}$ & $\begin{array}{l}0.210^{* * *} \\
(0.005)\end{array}$ \\
\hline Population pressure & $\begin{array}{l}-0.016^{* * *} \\
(0.004)\end{array}$ & $\begin{array}{l}0.444^{* * *} \\
(0.004)\end{array}$ & $\begin{array}{l}0.363^{* * *} \\
(0.004)\end{array}$ & $\begin{array}{l}-0.016^{* * *} \\
(0.004)\end{array}$ \\
\hline Relative per capita income & $\begin{array}{l}-0.139 * * * \\
(0.001)\end{array}$ & $\begin{array}{l}-0.215^{* * *} \\
(0.001)\end{array}$ & $\begin{array}{l}-0.176 * * * \\
(0.001)\end{array}$ & $\begin{array}{l}-0.140 * * * \\
(0.001)\end{array}$ \\
\hline ICRG rating consumer confidence & $\begin{array}{l}-0.050^{* * *} \\
(0.003)\end{array}$ & $\begin{array}{l}-0.210^{* * *} \\
(0.003)\end{array}$ & $\begin{array}{l}-0.199 * * * \\
(0.003)\end{array}$ & $\begin{array}{l}-0.050 * * * \\
(0.003)\end{array}$ \\
\hline ICRG rating unemployment & $\begin{array}{l}-0.034 * * * \\
(0.004)\end{array}$ & $\begin{array}{l}0.092^{* * *} \\
(0.004)\end{array}$ & $\begin{array}{l}0.023^{* * *} \\
(0.004)\end{array}$ & $\begin{array}{l}-0.033^{* * *} \\
(0.004)\end{array}$ \\
\hline ICRG rating poverty & $\begin{array}{l}0.375^{* * *} \\
(0.006)\end{array}$ & $\begin{array}{l}0.175^{* * *} \\
(0.006)\end{array}$ & $\begin{array}{l}0.316^{* * *} \\
(0.006)\end{array}$ & $\begin{array}{l}0.374^{* * *} \\
(0.006)\end{array}$ \\
\hline ICRG rating ethnic tensions & $\begin{array}{l}-0.123^{* * *} \\
(0.003)\end{array}$ & $\begin{array}{l}-0.132^{* * *} \\
(0.003)\end{array}$ & $\begin{array}{l}-0.156^{* * *} \\
(0.003)\end{array}$ & $\begin{array}{l}-0.122^{* * *} \\
(0.003)\end{array}$ \\
\hline ICRG rating internal conflict & $\begin{array}{l}-0.033^{* * *} \\
(0.001)\end{array}$ & $\begin{array}{l}-0.076^{* * *} \\
(0.001)\end{array}$ & $\begin{array}{l}-0.051^{* * *} \\
(0.001)\end{array}$ & $\begin{array}{l}-0.034^{* * *} \\
(0.001)\end{array}$ \\
\hline Average temperature (in Celsius) & $\begin{array}{l}0.213^{* * *} \\
(0.004)\end{array}$ & $\begin{array}{l}0.199 * * * \\
(0.003)\end{array}$ & $\begin{array}{l}0.143^{* * *} \\
(0.003)\end{array}$ & $\begin{array}{l}0.216^{* * *} \\
(0.004)\end{array}$ \\
\hline Average precipitation (in $\mathrm{mm}$ ) & $\begin{array}{l}0.021^{* * *} \\
(0.000) \\
(0.004)\end{array}$ & $\begin{array}{l}0.012^{* * *} \\
(0.000)\end{array}$ & $\begin{array}{l}0.014^{* * *} \\
(0.000)\end{array}$ & $\begin{array}{l}0.021^{* * *} \\
(0.000) \\
(0.004)\end{array}$ \\
\hline Contiguity & $\begin{array}{l}-0.186 \\
(2.470)\end{array}$ & & & \\
\hline Common official language & $\begin{array}{l}5.757^{*} \\
(3.130)\end{array}$ & & & \\
\hline Former colony & $\begin{array}{l}-8.532^{* *} \\
(3.297)\end{array}$ & & & \\
\hline $\begin{array}{l}\text { Distance in logs (simple distance between most } \\
\text { populated cities, in } \mathrm{km} \text { ) }\end{array}$ & $\begin{array}{l}-0.476 \\
(0.607)\end{array}$ & & & \\
\hline $\begin{array}{l}\text { Asylum requests to other European countries } \\
\text { (bias control) }\end{array}$ & $\begin{array}{l}-3.343^{* * *} \\
(0.041)\end{array}$ & $\begin{array}{l}-3.649^{* * *} \\
(0.016)\end{array}$ & $\begin{array}{l}-0.479 * * * \\
(0.019)\end{array}$ & $\begin{array}{l}-3.353^{* * *} \\
(0.041)\end{array}$ \\
\hline Time trend & & $\begin{array}{l}0.089 * * * \\
(0.000)\end{array}$ & & \\
\hline Dummy for year_after_2014 & & & $\begin{array}{l}1.454^{* * *} \\
(0.004)\end{array}$ & \\
\hline Observations & 1,447 & 1,447 & 1,447 & 1,447 \\
\hline Number of origin countries & 115 & 115 & 115 & 115 \\
\hline Origin fixed effects & No & Yes & Yes & Yes \\
\hline Year fixed effects & Yes & Trend & Time dummies & Yes \\
\hline Pseudo- $R^{2}$ (not adjusted for degrees of freedom) & - & 0.856 & 0.882 & 0.912 \\
\hline
\end{tabular}

Notes: Standard errors in parentheses; ${ }^{* * *} p<0.01,{ }^{* *} p<0.05,{ }^{*} p<0.1$; period 2001-2017; all variables are lagged by one period; an increase in the socioeconomic (consumer confidence, unemployment, and poverty) and security variables (ethnic tensions and internal conflict) implies an improvement so that a negative sign is expected; the sub-components poverty, unemployment, consumer confidence are only available from 2001 onwards; all variables are from the perspective of the origin country. 
To study asylum migration for specific country groups we now differentiate origin countries according to whether they are characterized as having high hrecog, medium mrecog, or low percentages Irecog of asylum approvals (see Table B5 in the Supplementary File). These countries cover only the most important asylumseeking countries as their dynamics are most interesting to understand.

In the sub-sample of hrecog countries (Afghanistan, Iraq, Syria, Eritrea, Somalia; see Table B5, column 1, in the Supplementary File) a 1-point improvement in ethnic tensions reduces asylum requests by $8 \%$, i.e.:

$$
[(\exp (-0.136+0.054)-1) \times 100=-0.08] ;
$$

a 1-point improvement in internal conflict reduces asylum requests by $7 \%$, i.e.:

$$
[(\exp (+0.055-0.245-1) \times 100=-0.07] .
$$

This points to a disproportionately small decline in asylum requests of hrecog countries if political factors improve and/or a persistence of the poor security situation in this country group.

In the sub-sample of mrecog countries (Pakistan, Turkey, Russia, Egypt, Nigeria, Ethiopia, Ghana, Guinea; see Table B5, column 2, in the Supplementary File) a 1-point improvement in ethnic tensions reduces asylum requests by $4 \%$, i.e.:

$$
[(\exp (-0.210+0.172)-1) \times 100=-0.04] ;
$$

a 1-point improvement in internal conflict increases asylum requests by $3 \%$, i.e.:

$$
[(\exp (-0.057+0.085-1) \times 100=0.03]
$$

This implies an inelastic reaction in asylum applications of mrecog countries and might be a plausible response by individuals who consider filing asylum requests a chance.

In the sub-sample of Irecog countries (BosniaHerzegovina, Georgia, Macedonia, Guinea-Bissau, Niger, Benin, Mali, India, Morocco; see Table B5, column 3, in the Supplementary File) a 1-point improvement in ethnic tensions reduces asylum requests by $28 \%$, i.e.:

$$
\text { [(exp }(-0.093-0.233)-1) \times 100=-0.28] \text {; }
$$

a 1-point improvement in internal conflict reduces asylum requests by $17 \%$, i.e.:

$$
[(\exp (-0.037-0.145)-1) \times 100=-0.17] \text {. }
$$

In this group we find a disproportionately large decrease in asylum applications, supposedly because the chance of being recognized as an asylee are low anyway and become even lower due to lower political risk.

\section{Discussion and Conclusions}

The purpose of the present research is to analyze how economic, socioeconomic, political, and climate-related factors influence migration (total and asylum-driven) from different countries to Germany. The results, which are condensed in Tables 1 and 2, are discussed below.

We observe, for total migration levels, moderate migration-decreasing effects of factors that are related to weaker migrant networks in Germany, smaller population growth differences between the countries of origin and Germany, relative economic progress in the countries of origin compared to Germany, and an improvement of socioeconomic factors, such as poverty, unemployment, and consumer confidence (as defined by the ICRG), in the sending countries. We also find consistent migration-decreasing effects from an improvement of political factors in the sending countries. This means that an improvement of the political situation in origin countries, such as Bulgaria, Romania, Hungary, Albania, Bosnia and Herzegovina, Serbia, or Turkey, could reduce the number of migrants.

In terms of asylum migration, improvements in ethnic tensions or internal conflict are associated with a lower number of asylum applications showing that people react to political improvements. These reductions are very pronounced in countries with a low asylum recognition rate. People in this country group possibly file fewer asylum applications as they supposedly believe that there will be a low likelihood of becoming recognized as asylees if the security situation in their home country improves. Improvements in economic and socioeconomic conditions in origin countries, such as relative improvements in per capita income, consumer confidence, and a reduction in unemployment are associated with a reduction in asylum requests. However, and perhaps contrary to expectation, alleviation of poverty seems to propel asylum migration suggesting that improved economic conditions, together with the help of families and facilitators, can make emigration feasible and affordable.

Hence, poverty in origin countries seems to play a double role in explaining total and asylum migration flows. On the one hand, alleviation of poverty (for instance, in Eastern and South European countries) reduces total migration as the income differential between origin countries and Germany diminishes and the need to work in Germany becomes less pressing. On the other hand, alleviation in poverty in comparatively poorer economies (primarily developing countries) can propel migration by generating the financial means for departure.

With regards to climate variables, increasing average temperatures is mostly negatively correlated with total migration flows. However, and completely contrary to the former finding, we see that increasing average temperatures trigger emigration among asylum seekers. Interestingly, the majority of asylum seekers comes predominantly from countries located in arid and semi-arid regions, where increasing average temperatures lead to drought with concomitant high losses in agriculture. An aggravating factor is that agriculture and pastoralism are the dominant income sources in these regions 
and are practiced to a great extent as subsistence agriculture is characterized by low resilience. Hence, the resulting losses also in food production cannot be compensated and destroy the means of existence leading to rural exodus to urban areas. Consequently, migration to cities can result in over-crowding and ethnic conflicts can eventually drive long-distance migration. Increases in average precipitation also due to climate change have a migration-increasing effect, having a minor impact on total migration and a somewhat higher impact on asylum migration. However, the precipitation effect is less pronounced compared to the effect of an increase in average temperature. Increasing average precipitation rates can lead to floods and a loss of livelihood, but the weaker effect on asylum migration is probably due to the expectations of recovering one's home and land after the flood. Expected aid by authorities or foreign institutions may also play a role in lowering pressure on asylum migration.

To the extent that the economic crises stemming from the Covid-19 pandemic and a deterioration of economic conditions might lead to more political turmoil and conflicts in the developing world, we should expect an increase in total migration and asylum migration flows in the coming years.

We leave for further research a specific analysis of the climate-related factors and an analysis of other OECD countries at a similar detailed level, as this could provide a comparative framework to deeper examine the determinants of migration in origin countries. Another important aspect to be examined is the role played by German aid facilitating or deterring migration depending on the level of development of the sending countries and the type of aid.

\section{Acknowledgments}

The authors would like to thank Sarah Frohnweiler for excellent research assistance and late Prof. Stephan Klasen for giving us the opportunity to do research on migration. Martinez-Zarzoso is also grateful for the financial support received from Project PID2020-114646RBC42 at the Ministerio de Economía y Competitividad, PROMETEO2018/108 (Generalitat Valenciana), and from project UJI-B2020-57 (Universitat Jaume I).

\section{Conflict of Interests}

The authors declare no conflict of interests.

\section{Supplementary Material}

Supplementary material for this article is available online in the format provided by the author (unedited).

\section{References}

Ayoub, M. (2019). Understanding Germany's response to the 2015 refugee crisis. Review of Economics and
Political Science. Advance online publication. https:// doi.org/10.1108/REPS-03-2019-0024

Backhaus, A., Martinez-Zarzoso, I., \& Muris, C. (2015). Do climate variations explain bilateral migration? A gravity model analysis. IZA Journal of Migration, 4(3). https://doi.org/10.1186/s40176-014-0026-3

Beine, M., Docquier, F., \& Özden, C. (2011). Diasporas. Journal of Development Economics, 95(1), 30-41.

Bertoli, S., Brücker, H., \& Fernández-Huertas Moraga, J. (2016). The European crisis and migration to Germany. Regional Science and Urban Economics, 60(6). https://doi.org/10.1016/j.regsciurbeco.2016.06.012

Bertoli, S., Brücker, H., \& Fernández-Huertas Moraga, J. (2020). Do processing times affect the distribution of asylum seekers across Europe? (IZA Discussion Paper 13018). Institute of Labor Economics.

Bertoli, S., \& Fernández-Huertas Moraga, J. (2013a). Crossing the border: Self-selection, earnings and individual migration decisions. Journal of Development Economics, 101(1), 75-101.

Bertoli, S., \& Fernández-Huertas Moraga, J. (2013b). Multilateral resistance to migration. Journal of Development Economics, 102(C), 79-100.

Bundesinstitut für Bevölkerungsforschung. (2020). Fakten-Spätaussiedler nach Herkunftsländern (1990-2019) [Facts-Late repatriates classified by countries of origin (1990-2019)]. https://www.bib. bund.de/Permalink.html?id=10283280

Capps, R., Meissner, D., Ruiz Soto, A. G., Jessica Bolter, J., \& Pierce, S. (2019). From control to crisis: Changing trends and policies reshaping U.S.-Mexico border enforcement. Migration Policy Institute.

Davenport, C. A., Will, H. M., \& Poe, S. C. (2003). Sometimes you just have to leave: Domestic threats and forced migration, 1964-1989. International Interactions, 29(1), 27-55.

De Haas, H., Czaika, M., Flahaux, M.-L., Mahendra, E., Natter, Vezzoli, K., \& Villares-Varela, M. (2019). International migration: Trends, determinants, and policy effects. Population and Development, 45(4), 885-922.

Deutscher Bundestag. (2014). Schriftliche Stellungnahme des Präsidenten des Bundesamts für Migration und Flüchtlinge, Dr. Manfred Schmidt (Ausschussdrucksache 18(19)069f) [Statement of the president of the Federal Office for Migration and Refugees, Dr. Manfred Schmidt (Print issue 18(19)069f)] https://www.bundestag.de/resource/ blob/282440/af27eac30d89444e26605d6122d659 c7/schmid_stellungnahmet-data.pdf

Giulietti, C., Schluter, C., \& Wahba, J. (2013). With a lot of help from my friends: Social networks and immigrants in the UK. Population, Space and Place, 19(6), 657-670.

Grogger J., \& Hanson, G. H. (2011). Income maximization and the selection and sorting of international migrants. Journal of Development Economics, 95(1), 42-57. 
Gröschl, J., \& Steinwachs, T. (2017). Do natural hazards cause international migration? CESifo Economic Studies, 63(4), 445-480.

Grote, J. (2018). The changing influx of asylum seekers in 2014-2016: Responses in Germany. Federal Office for Migration and Refugees.

Hatton, T. J. (2004). Seeking asylum in Europe. Economic Policy, 19(38), 6-62. https://doi.org/10.1111/j.14680327.2004.00118.x

Hatton, T. J. (2009). The rise and fall of asylum: What happened and why? Economic Journal, 119(535), F183-F213. https://doi.org/10.1111/j.1468-0297. 2008.02228.x

Hatton, T. J. (2016). Refugees, asylum seekers, and policy in OECD countries. American Economic Review, 106(5), 441-445. https://doi.org/10.1257/aer. p20161062

Hatton, T. J. (2017). Refugees and asylum seekers, the crisis in Europe and the future of policy. Economic Policy, 32(91), 447-496.

Hatton, T. J. (2020). Asylum migration to the developed world. Persecution, incentives, and policy. Journal of Economic Perspectives, 34(1), 75-93.

Hatton, T. J., \& Moloney, J. (2015). Modelling asylum claims by origin and destination. In M. McAuliffe \& K. Koser (Eds.), A long way to go: Irregular migration, patterns, processes, drivers and decision-making (pp. 227-254). ANU Press.

Hoeffler, A. (2013). Out of the frying pan into the fire? Migration from fragile states to fragile states. OECD. https://doi.org/10.1787/5k49dffmjpmv-en

Iglit, A., \& Klotz, A. (2018). Refugee rights or refugees as threats? Germany's new asylum policy. The British Journal of Politics and International Relations, 20(3), 613-631.

Kang, Y. D. (2021). Refugee crisis in Europe: Determinants of asylum seeking in European countries from 2008-2014. Journal of European Integration, 43(1), 33-48.

Mayda, A. M. (2010). International migration: A panel data analysis of the determinants of bilateral flows. Journal of Population Economics, 23, 1249-1274. https://doi.org/10.1007/s00148-009-0251-x

Missirian, A., \& Schlenker, W. (2017). Asylum applica- tions respond to temperature fluctuations. Science, 358, 1610-1614.

Müller, B., Haase, M., Kreienbrink, A., \& Schmid, S. (2012). Klimamigration: Definition, Ausmaß und politische Instrumente in der Diskussion [Climate migration: Definition, extent and political instruments under discussion]. Federal Office for Migration and Refugees.

OECD. (2019). International migration outlook [Database]. https://databank.worldbank.org/ source/world-development-indicators

OECD. (2020). International migration database [Database]. https://stats.oecd.org/Index.aspx?Data SetCode=MIG

PRS Group. (2019). International country risk guide.

Rotte, R., \& Vogler, M. (1998). Determinants of international migration: Empirical evidence from migration from developing countries to Germany (IZA Discussion Paper 12). Institute of Labor Economics.

Sachverständigenrat deutscher Stiftungen für Integration und Migration. (2010). Einwanderungsgesellschaft 2010 [Immigration society 2010]. Jahresgutachten mit Integrationsbarometer. https:// www.stiftung-mercator.de/content/uploads/2020/ 12/SVR_Jahresgutachten_2010.pdf

van Meeteren, M., \& Pereira, S. (2018). Beyond the 'migrant network'? Exploring assistance received in the migration of Brazilians to Portugal and the Netherlands. Journal of International Migration and Integration, 19, 925-944.

Villarrubia-Mendoza, J. (2016). Tú velas por los tuyos: Weak labor markets and the importance of social networks. Journal of International Migration and Integration, 17(2), 631-648.

Winter, S. (2020). It's the economy, stupid: On the relative impact of political and economic determinants on migration. Population Research and Policy Review, 39, 207-252.

World Bank. (2020). World development indicators. https://databank.worldbank.org/source/worlddevelopment-indicators

Zahra, T. (2016). The great departure: Mass migration from Eastern Europe and the making of the free world. W. W. Norton.

\section{About the Authors}

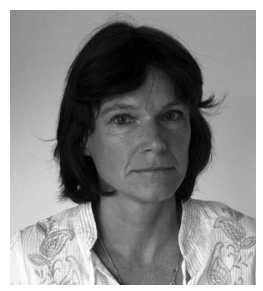

Felicitas Nowak-Lehmann (PhD) is a senior researcher at the Ibero-America Institute for Economic Research. She is also member of the Centre for Global Migration Studies (CeMig) of the University of Göttingen. Dr. Nowak's research interests comprise international trade, migration, and applied development economics, in particular aid effectiveness. Her work has been published in journals such as World Development, Journal of Common Market Studies, World Economy, Review of World Economics, Journal of Development Studies, Canadian Journal of Economics, and Applied Economics. 


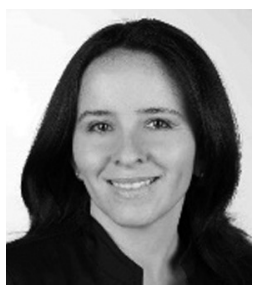

Adriana Cardozo (PhD) is a postdoctoral researcher at the Chair of Development Economics of Prof. Andreas Fuchs, University of Göttingen. Previously, she worked as economic analyst at the World Bank, as research fellow for the Inter-American Development Bank, and as a consultant for various development aid cooperation agencies (GIZ and Oxfam, among others). Dr. Cardozo's research interest focuses on the interaction between migration and labor market outcomes, the distributional aspects of trade agreements, and the similarity and evolution of international organizations.

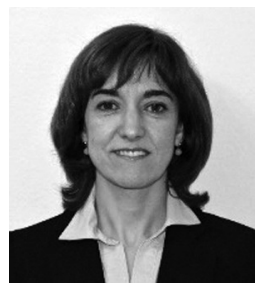

Inmaculada Martínez-Zarzoso is professor at the Universities of Göttingen (Germany) and Jaume I (Spain). She is also vice-chair of the International Network for Economic Research (INFER) and board member of the Centre for Global Migration Studies (CEMIG). She is the author of two books and of more than 100 articles in academic journals, including the Journal of International Economics and the Journal of Development Economics, in the fields of international and development economics. https://orcid.org/0000-0002-3247-8557 